\title{
Position of Price in Determinants of Quality of Products (Case Study)
}

\author{
Arash Hoseinkhani1, Mohsen Nazari'1, Fereshteh Farzianpour ${ }^{2 *}$, Shadi Hosseini1 \\ ${ }^{1}$ Department of Management, University of Tehran Kish International Campus, Tehran, Iran \\ ${ }^{2}$ Department of Health Management and Economics, School of Public Health, Tehran University of Medical \\ Sciences, Tehran, Iran \\ Email: arash.tera@yahoo.com, farzianp@sina.tums.ac.ir, ‘farzianp2@yahoo.com
}

Received 7 November 2014; accepted 21 March 2015; published 23 March 2015

Copyright (C) 2015 by authors and Scientific Research Publishing Inc.

This work is licensed under the Creative Commons Attribution International License (CC BY).

http://creativecommons.org/licenses/by/4.0/

(c) (i) Open Access

\section{Abstract}

Price plays a significant role in product quality in today communities, and consumers may not be aware of the quality and characteristics of the products they buy, despite of presence of distinctive products. They often are not able to compare different brands in terms of the quality. Although many studies on price-quality relationship support this common belief, some other studies indicate that this relationship depends on the specific type of the product, and overall presence of such relationship is less probable. Current work aims at investigating the relationship between product price and purchaser perception of the quality in durable, less durable and non-durable products in Kish Island's markets as a case study. Three selected products include: LED TV as a durable product, $t$-shirts as a semi-durable product, and toothpaste as a non-durable product. Research tool is a questionnaire and collected data are analyzed using SPSS V.19 software. Results of the research indicate that price is one of factors reflecting the quality. It was true about $t$-shirt more than two other products.

\section{Keywords}

Product Quality, Perceived Quality, Purchase Intention, Price, Quality

\section{Introduction}

Reviewed literature indicates that there is no close relationship between product quality and price in today economy, and this pattern is true only for some specific products including lucrative ones [1]. Considering these findings, it can be logically expected that lower price of products facilitates accessibility and in turn, high price

\footnotetext{
${ }^{*}$ Corresponding author.
}

How to cite this paper: Hoseinkhani, A., Nazari, M., Farzianpour, F. and Hosseini, S. (2015) Position of Price in Determinants of Quality of Products (Case Study). Journal of Service Science and Management, 8, 149-160. 
is an obstacle for accessibility [2]. Thus, this probability can be raised that more expensive products are less accessible and referred due to financial obstacles [3]. In turn, cheaper products provide higher accessibility and are more referred. Despite of distinctive products, consumers may not be aware of the quality and features of the products they buy. They often are not able to compare different brands in terms of quality [4]. In addition, they collect less information even in conditions that financial matter and the price are considered [5]. A famous belief states that "You get what you pay for", and thus the consumers tend to believe that the higher price suggests higher quality for the product. Considering above facts, the role of price is considered significant. Current work aims at investigating if higher price suggests higher quality.. It attempts to explore relationship between product price and perception of the purchaser about the product quality in durable, semi-durable and non-durable products among customers of LED TV products as a durable product, t-shirt as a semi-durable product and toothpaste as a non-durable product in Kish Island. Price is one of the main elements of marketing and it is the only factor of the marketing mix which is profitable for the company. Also in consumer perspective, price has high sensitivity, so that price of a product is measured along with the quality which is perceived and expected from the product. Considering specific ranges of the price, consumers expect that higher price reflects higher quality. The higher is price of a product, its perceived value will be lower. Perceived value is a tradeoff which the consumer performs when evaluating the brand between price and perceived quality [6]. The customer considers five main factors as indexes for his selection so that he will select and purchase the product. These factors include: quality, price, available delivery, flexibility and variety in the products for various tastes, and after sales service. These five factors have specific advantages which can be criterion for purchaser's decision making. Two indexes are more important: quality and price. If a customer decides to prepare a product, he will consider the product cost (price) when the product quality is thought. No one expects to buy a complex product in a low price, since the quality, performance, price and famous brand of the product should be considered. The important point for the customer is the price for purchasing the product, which should be logically proportionate to the type of product. Establishing such proportionality leads to customer decision to purchase the product. If the purchaser feels that he pays excessively and the product's quality does not fit the price, he would feel dissatisfied [7]. Following questions may come to the minds of the audiences: What is the relationship between price and quality? Does the product with higher price have always higher quality? Should the producers and sellers seek for promoting their product quality to absorb customers or they should reduce the price by decreasing the profit margin? Should always positive relationship between quality and price be stressed or the new market conditions have disturbed this equation and relation? These questions and like that cause that the author seeks for investigating relationship between product price and purchase perception about the product quality. Performing this research study helps producers and marketers apply quality indexes for consumers to perceive make decision on pricing, advertisement, etc.

\section{Theoretical Foundations}

Quality: quality of the product of any type is the foremost matter in the consumption market. No one tends to pay money and receive a product in a lower value. It is not also logical. Today the most optimal product is one which fulfills wish of the customers. The whole organization is today committed to the quality. Quality is the essence of the organization and satisfied customers are resources of the companies [8].

Although the authors have long investigated relationship between signaling quality through quality tools, it was not the whole path, rather it was an initiation for paying attention to other aspects of quality signaling so that signaling theory essentially appeared for exploring all ways and elements leading to quality diagnosis in information asymmetry conditions, and then these elements and their relationships with quality of the products were considered. One side which is usually information sender specifies the type and way of information signal and the other side which is receiver interprets the signals. Thus, signally theory have dominant role in management literature. For example, it is observed in strategic management, entrepreneurship, and human resources. Although signally role has become more evident in recent years, its main focus can be observed in organizational issues [9]. Price is one of the main elements of marketing and it is the only factor in marketing mix which is profitable for the company. Also in consumer perspective, price has high sensitivity, so that price of a product is measured along with the quality which is perceived and expected from the product. Considering specific ranges of the price, consumers expect that higher price reflects higher quality. The higher is price of a product, its perceived value will be lower. Perceived value is a tradeoff which the consumer performs when evaluating the 
brand between price and perceived quality [6].

According to Murphy (2002), investigation of product price and quality relationship in USA dates back to 1059. Murphy maintains that in a market with high level of competition where cost of product search for the consumer is low, it is expected there is positive relationship between price and quality. In such conditions, producers of higher quality products are able to sell their products in higher price. On the other hand, producers of lower quality products are not able to compete and gradually will be excluded from the market. In the conditions that cost of recognition of different qualities is high or not possible, quality based pricing would not be possible. In such conditions, producers of products with varying qualities receive the same money and finally the market would shift toward low quality products, while overall market strategy is shift toward higher quality products. Thus, recognizing relationship between price and quality and providing practical models for measurement of this relationship is highly crucial [10]-[12].

\section{Review of Literature}

\subsection{Domestic Works}

Investigating relationship between quality and final price of information products: case study of books in information sciences provided in AMAZON Online Store was done by Ebrahimi and Farajbahloo. In their review study, they found that quality and price are two important variables in information economics which constitute basic elements of management decisions. Studies on relationship between two variables suggest that there is no significant relationship between two variables price element cannot be as a criterion for acceptance of the product's quality. In this regard, information products follow general pattern for other products, because it is true also about majority of the general products. These findings can be useful for decision making by the managers involved in information economics, managers in information centers, libraries and other centers which are somehow related to information provision [11].

\subsection{Foreign Works}

Role of information prior to purchase in evaluation of the quality and variety was examined by [13]. Multiple competitions were considered in this model, so that several companies are present which offer various consuming products. The companies invest on their products' quality, thus evaluation of the customers for their products is increased and they receive special evaluation prior to product purchase. Even after receiving signals related to the quality, customers are not certain about the utility they would receive from the product purchase. Accuracy if information prior to purchase specifies the price, quality and variety. It has been proved that perceived quality is always increased by the received information, however, impact of the price increase and variety decrease on the quality is always ambiguous. Quality and variety are always in inverse relation.

Meng and Tian (2011) examined relationship between price and advertisement and quality in products which their quality is not clear for the customers. They found that when there is maximum consumption for the product, ability of the companies in signaling quality through price increase is highly limited. Also, relationship between price-quality and advertisement-quality, which was strongly supported in the literature, is not present in this work. It should be considered that the market under study in this work is an exclusive market and has been tested in terms of repeated purchase [14].

Tsui (2012) focused on cellphone market and studied tendency to payment by consumers before and after observing advertisement. Their findings showed that effective advertisement increases perceived quality as well as tendency for payment in the consumers. Also, their findings indicated although investment in high and low quality products varies, influence of the advertisement in increasing tendency for payment for low quality products is as good as influence of advertisement in increasing tendency for payment for high quality products [15].

Arnold and Frank wick (2012) study influence of relationship between customers on their perceived role and their tendency to participate in service process, quality perception ad satisfaction, also, this work studies relationship between C2C both in clear and conflict conditions. 427 questionnaires were distributed among customers of a hospital. Findings of the research suggest perceived role of customers adjusts $\mathrm{C} 2 \mathrm{C}$ relationship of the customers and their participation, while perception of fair service delivery influences $\mathrm{C} 2 \mathrm{C}$ relationship and role of variables. Perceived role of customers directly and indirectly affects customer satisfaction through participation and quality perception [16] [17]. 
Despite the wide research done on the relationship between quality and price, literature found conflicting results for this relationship. Therefore, the present study tries to find a relationship between buyer's perception of the quality of products in a wide range of prices as well as a relationship between high price and buyer's perception of the quality of a product in regard to durable (color TV), lowly durable (t-shirt) and non-durable (shortlived) products.

\section{Methodology and Data Collection}

Steps for this research can be classified in two groups as follows: 1) Initial exploratory study using the theoretical background of the study (definitions, approaches and models), studying experimental background of the study (domestic and foreign works) and interview (with the scientific and academic experts), 2) Using a questionnaire (to determine opinion of customers to investigate the relationship between product price and the perception of the purchaser about its quality in durable, semi-durable and non-durable products in Kish Island) (see Appendix).

\subsection{Statistical Population and Sample}

Statistical sample in this work include all costumers of shopping centers in Kish Island who bought at least one product in these centers. Statistical population of this research includes purchasers who shopped in Kish shopping centers which cover two groups: 1) Tourists, which their number is limited, 2) Residents of the Kish Island.

Considering the plan conditions and recognition of the statistical population as well as extensive geographical coverage of the research, stratified sampling is used in this work. In costumer part, since volume of the shopping centers was high in Kish Island and there was time limitation, stratified sampling was used. Sampling included two steps:

Step 1: Kish shopping centers including three shopping centers in Kish Island. Step 2: customers of selected shopping centers.

\subsection{Measurement Tools}

The author investigated research hypotheses and research questions using questionnaire. In order to determine validity of the questionnaire, content validity was used and Cronbach's alpha coefficient was used to ensure accurate measurement capabilities of the research tool. Data analysis was performed using SPSS v.19 software. Statistical tools used for data analysis in descriptive statistics included tables, frequency distribution, mean, standard deviation, and inferential statistics included one sample t-test, two-sample t-test, and the Friedman test.

\subsection{Questionnaire Validity and Reliability}

Concept of validity answers the question that to what extent the questionnaire measures the characteristics. In this step, sentencing of the items, readability and interpretation of items, adequacy of items, suitability of items, etc. are measured. To this end, the designed questionnaire was given to the marketing and statistics professors in Tehran and Kish universities and some other field experts. Following obtaining their ideas and performing modifications, the questionnaire validity was confirmed. Cronbach's alpha coefficient was used for calculating reliability. Cronbach's alpha coefficient is used for calculating internal consistent of the measurement tool including questionnaires. Reliability is one of the technical characteristics of measurement tool. This concept deals with the fact that to what extent the measurement tool provides similar results in identical conditions. Reliability coefficient ranges from 0 (non-relevant) to +1 (totally relevant). Reliability coefficient suggests to what extent the measurement tool measures stable characteristics of the subject or its variable and temporary characteristics. In order to calculate Cronbach's alpha coefficient, firstly variance of the scores in each sub-set of items should be calculated and total variance should be calculated [13].

\section{Research Findings}

\subsection{Findings Related to t-Shirt Items}

In investigating the frequency in terms of gender, 120 cases were usable, 46.7 percent of which were females and 53.3 percent were males. Age focus of respondents was 20 - 30 and 30 - 40 years. In terms of education, 
majority of respondents had BA. In terms of residency, mostly of respondents were not residents of Kish Island.

T-test is used for investigating average response to the items so that status of variables in average is specified. The hypothesis on population mean is investigated in this test at error level 5 percent $(\alpha=5 \%)$. Considering use of SPSS software in this work which provides significance level after calculation of average of responses, if Sig. statistics is smaller than 5 percent, it is clear that average of responses to items is not in mean level, that is, H1 is accepted and if Sig. statistics is larger than 5 percent, null hypothesis is supported.

\section{Kolmogorov-Smirnov Test}

Considering Table 1, it is observed that purchase and quality have significance level above 0.05 and they are normal, and variable related to price and market are not normal due to significance level 0.001 .

In order to use two-sample t-test, presence of a quantitative variable and categorical variable (including two categories) is necessary. Four quantitative variables are considered along with demographic variables in this section. If sig level is larger than 0.05 , influence of demographic variable on quantitative variables of the model is rejected. If $\mathrm{t}$ is larger than 1.96, i.e. mean of first sample is larger than second one. If $\mathrm{t}$ is smaller than -1.96 , i.e. mean of first sample is smaller than second one, and if $t$ is between 1.96 and -1.96 , two samples are equal.

\subsection{Findings Related to LED Items}

In investigating the frequency in terms of gender, 120 cases were usable, 42.5 percent of which were females and 57.5 percent were males. Age focus of respondents was 30 - 40 years. In terms of education, majority of respondents had BA. In terms of residency, mostly of respondents were not residents of Kish Island.

\section{Two-Sample t-Test}

Considering Table 2, it is observed two variables (purchase and quality) have significance level above 0.05 and they are normal, and variable related to price and market are not normal due to significance level 0.001 and 0.004 .

\subsection{Findings Related to Toothpaste Items}

In investigating the frequency in terms of gender, 384 cases were usable, 41.7 percent of which were females and 58.3 percent were males. Age focus of respondents was 30 - 40 years. In terms of education, majority of respondents had BA. In terms of residency, mostly of respondents were not residents of Kish Island.

\subsubsection{Two-Sample t-Test}

Considering Table 3, it is observed two variables (Purchase and Quality) have significance level above 0.05 and

\begin{tabular}{cccc} 
Table 1. Results of Kolmogorov-Smirnov test. & \\
\hline Variable & Kolmogorov-Smirnov test & Sig. level $(p$ value $)$ & No. \\
\hline Purchase & 1.140 & 0.149 & 120 \\
Quality & 1.357 & 0.050 & 120 \\
Price & 1.970 & 0.001 & 120 \\
Market & 1.850 & 0.001 & 120 \\
\hline
\end{tabular}

Table 2. Results of Kolmogorov-Smirnov test.

\begin{tabular}{cccc}
\hline Variable & Kolmogorov-Smirnov test & Sig. level $(p$ value $)$ & No. \\
\hline Purchase & 1.005 & 0.265 & 120 \\
Quality & 1.075 & 0.198 & 120 \\
Price & 1.966 & 0.001 & 120 \\
Market & 1.747 & 0.004 & 120 \\
\hline
\end{tabular}


Table 3. Results of Kolmogorov-Smirnov test.

\begin{tabular}{cccc}
\hline Variable & Kolmogorov-Smirnov test & Sig. level $(p$ value $)$ & No. \\
\hline Purchase & 0.920 & 0.366 & 120 \\
Quality & 1.058 & 0.213 & 120 \\
Price & 1.443 & 0.031 & 120 \\
Market & 1.582 & 0.013 & 120 \\
\hline
\end{tabular}

they are normal, and variable related to price and market are not normal due to significance level 0.031 and 0.013 .

Research hypotheses are raised as follows:

1) Perception of quality depends on the price.

2) Women consider price as index of quality more than men.

3) Passengers consider price as index of quality more than residents.

4) Perception of the price-quality in non-durable products is more than durable products.

\subsubsection{Results for Research Analytical Statistics}

H1: Perception of quality depends on the price.

Considering the tests (one-sample t-test and Friedman test) in all three questionnaires it is concluded that perception of quality depends on the price. That is, goods and products with higher price have higher quality in the minds of consumers. Thus, $\mathrm{H} 1$ is supported.

H2: Women consider price as index of quality more than men.

Two-sample test was used in order to test this hypothesis.

In order to use two-sample t-test, presence of a quantitative variable and categorical variable (including two categories) is necessary. Four quantitative variables are considered along with demographic variables in this section. If sig level is larger than 0.05 , influence of demographic variable on quantitative variables of the model is rejected. If $\mathrm{t}$ is larger than 1.96, i.e. mean of first sample is larger than second one. If $\mathrm{t}$ is smaller than -1.96 , i.e. mean of first sample is smaller than second one, and if $t$ is between 1.96 and -1.96 , two samples are equal.

\subsection{Findings Related to t-Shirt Items}

Considering results obtained in quality variable, sig. level is 0.140 , which is larger than 0.05 , and $t$ value is -0.179 in women and -0.181 in men, which is between 1.96 and -1.96 . Thus, impact of gender variable on the quality is rejected. That is, both men and women identically consider price as index of quality.

\subsection{Findings Related to Toothpaste Items}

Considering results obtained in quality variable, sig. level is 0.307 , which is larger than 0.05 , and $t$ value is -0.308 in women and -0.385 in men, which is between 1.96 and -1.96 . Thus, impact of gender variable on the quality is rejected.

That is, both men and women identically consider price as index of quality. Given the test (comparison of two sample mean) in three questionnaires, it is concluded that women and men identically consider price as index of quality. Thus, $\mathrm{H} 2$ is not supported (Table 4).

H3: Passengers consider price as index of quality more than residents.

\subsection{Findings Related to t-Shirt Items}

Considering results obtained in quality variable, sig. level is 0.639 , which is larger than 0.05 , and t value is 0.362 in women and 0.374 in men, which is between 1.96 and -1.96 . Thus, impact of residency variable on the quality is rejected. That is, both passengers and residents identically consider price as index of quality.

\subsection{Findings Related to LED Items}

Considering results obtained in price variable, sig. level is 0.145 , which is larger than 0.05 , and t value is -0.100 
Table 4. Results of comparison between genders.

\begin{tabular}{ccccccccc}
\hline \multirow{2}{*}{ Purchase } & & Gender & $\mathrm{N}$ & Mean & Mean & Sig level & $\mathrm{t}$ & Result \\
& Female & 50 & 3.5994 & 0.78455 & 0.10986 & & -0.731 & \\
& Male & 70 & 3.7102 & 0.85020 & 0.10162 & & -0.740 & Equal \\
\multirow{2}{*}{ Quality } & Female & 50 & 3.5994 & 0.84081 & 0.11774 & & -0.380 & \\
& Male & 70 & 3.6612 & 0.91333 & 0.10916 & & -0.385 & Equal \\
& Female & 50 & 3.5033 & 0.48704 & 0.06820 & & 0.835 & \\
\multirow{2}{*}{ Price } & Male & 70 & 3.4095 & 0.68553 & 0.08194 & & 0.076 & Equal \\
& Female & 50 & 11.2941 & 0.41977 & 0.05878 & & & \\
& Male & 70 & 11.1333 & 0.44469 & 0.05315 & & 2.010 & Equal \\
\hline
\end{tabular}

in residents and -0.109 in passengers, which is between 1.96 and -1.96 . Thus, impact of residency variable on the price is rejected. That is, both passengers and residents identically consider price as index of quality.

\subsection{Findings Related to Toothpaste Items}

Considering results obtained in price variable, sig. level is 0.288 , which is larger than 0.05 , and t value is 0.372 in women and 0.407 in men, which is between 1.96 and -1.96 . Thus, impact of residency variable on the price is rejected. That is, both passengers and residents identically consider price as index of quality. Given the test (comparison of two sample mean) in three questionnaires, it is concluded that passengers and residents identically consider price as index of quality. Thus, $\mathrm{H} 3$ is not supported.

Therefore, the results showed that price as index of quality between women and men and between residents and passengers in terms of t-shirt items and Toothpaste items is not significant and there is no difference between two groups (results is similar).

\section{Conclusions}

Consumers consider price as one of the main factors for purchase of the product. It is true about less-durable product such as t-shirt more than two other products. Regarding t-shirt, the price is in the second rank. In durable product such as LED TV and non-durable product such as toothpaste, it is in the rank after product characteristic, and brand is in the third rank. It can be concluded that in durable products, long term use of the product characteristics and brand are more important factors. In semi-durable product, people do not pay attention to the price due to low price of toothpaste and dental health, and consider brand and characteristics of the product higher than the price. Judgment on quality is considerably based on characteristic of the product. It is true for all three products. Thus, this factor is in the first rank for t-shirt and LED TV ad in the second rank for toothpaste.

Analysis of variables indicates that for all three products, purchasers pay more attention to the money with purchasing the brands. It is true more about toothpaste with first rank and LED with second rank and t-shirt with third rank. Respondents agree with this statement: "lower price of the product suggest lower quality of the product", and they deeply believe that "higher price indicates higher quality for the products." Purchasers believe that purchasing a brand with lower price is risky.

\section{Recommendations for Future Works}

1) LED TV: regarding LED TVs, low pricing leads to creating negative impact on perception of people in relation with the quality of this product. Consumers tend to purchasing cheap brands that are probably from low class of the society. Prices which are logically high hive high quality image to the product. However, marketers should be careful about pricing policies of the competitors and their target market's purchasing power.

2) t-Shirt: pricing for t-shirt is most difficult. The problem which is faced by the marketers in the market is that considerable part of their target market, that is, youth, especially students, has more limited purchasing power. They prefer local or non-famous brands of t-shirt over t-shirts with expensive brands. But if their pur- 
chasing power was higher, they certainly will give priority to famous brands of t-shirt. However, reducing t-shirt price may damage the brand image. Thus, marketers for t-shirt should adopt suitable market division strategy, select appropriate target market, and price the t-shirts accordingly.

3) Toothpaste: for toothpaste, brand image is the determinant factor and marketers should price products according to the brands favorite by people or similar to famous brands. However, relationship between price and quality for this product is weaker than two other products, i.e. LED TV and t-shirt. Marketers should consider that low pricing creates a very bad image of the quality in the minds of purchasers. Anyway, purchasers usually judge about this product based on their internal reference price. Thus, perceiving internal reference price of the purchasers seems necessary for marketers.

\section{References}

[1] Mohammadpour, A., Roshandel Arbatani, T., Hassan Holipour, T., Farzianpour, F. and Hosseini, S.H. (2014) A Survey of the Effect of Social Media Marketing on Online Shopping of Customers by Mediating Variables. Journal of Service Science and Management, 7, 368-376. http://dx.doi.org/10.4236/jssm.2014.75034

[2] Farzianpour, F., Aghababa, S., Delgoshaei, B. and Haghgoo, M. (2011) Performance Evaluation a Teaching Hospital Affiliated to Tehran University of Medical Sciences Based on Baldrige Excellence Model. American Journal of Economics and Business Administration, 3, 272-276. http://dx.doi.org/10.3844/ajebasp.2011.272.276

[3] Farzianpour, F., Pishdar, M., Shakib, M.D., Hashemi, S. and Toloun, M.R. (2014) Consumers’ Perceived Risk and Its Effect on Adoption of Online Banking Services. American Journal of Applied Sciences, 11, 47-56. http://dx.doi.org/10.3844/ajassp.2014.47.56

[4] Farzianpour, F., Rahimi Fouroshani, A., Vahidi, R.G.H., Arab, M. and Mohamadi, A. (2011) Investigating the Relationship between Organizational Social Capital and Service Quality in Teaching Hospitals. American Journal of Economics and Business Administration, 3, 425-429. http://dx.doi.org/10.3844/ajebasp.2011.425.429

[5] Farzianpour, F., Raheimi Fouroshani, A., Mohamadi, A. and Hosseini, S.S. (2013) Evaluation of the Relationship between Social Capital and Manpower's Burnout in Teaching Hospitals of Iran. African Journal of Business Management, 7, 2872-2881. http://www.academicjournals.org/AJBM

[6] Heydarzadeh, K. and Ghaffari (2009) Effect of Brand Name Recognition and Brand Interface on Purchase Behavior of Customers. Proceedings of the International Conference on Brand, 143.

[7] Aghaee, H. (2008) How to Evaluate Quality of Manufacturing Products? (Part I), Public Interest in Durable Goods. Kayhan Newspaper, No. 19225.

[8] Ebrahimi, M., Venus, D. and Rusta, A. (2009) Marketing Management (2). SAMT Publication.

[9] Connelly, B.L., Certo, S.T., Ireland, R.D. and Reutzel, C.R. (2011) Signaling Theory: A Review and Assessment. Journal of Management, 37, 39-67. http://dx.doi.org/10.1177/0149206310388419

[10] Murphy, R. (2002) The Correlative Relationship between Value, Price and Cost. Journal of American Academy of Business, 2, 204-210.

[11] Ebrahimi, S. and Farajpahloo, A. (2011) Relationship between Quality and Final Price of Products: A Case Study of Information Science Books on Amazon Shop. Journal of Library and Information Science, 13.

[12] Ezatabadi, M. (2011) Economic Study of Relationship between Price and Quality in Domestic Market of Iranian Pistachio, Case Study: Kerman Province. 14-19.

[13] Chegini, S. (2009) Identifying Factors Affecting Choice of Retailer by the Purchasers. Master's Thesis, Faculty of Social Sciences and Economics, Alzahra University, 32-56.

[14] Meng, S.-M., Liang, G.-S. and Yang, S.-H. (2011) The Relationships of Cruise Image, Perceived Value, Satisfaction, and Post-Purchase Behavioral Intention on Taiwanese Tourists. African Journal of Business Management, 5, 19-29.

[15] Tsui, A.S. (2012) Calling for Humanistic Scholarship in China. Management and Organization Review, 9, 1-15. http://dx.doi.org/10.1111/more.12013

[16] Arnold, J. and Frankwick, G.L. (2012) Should the Sales Manager Coach or Play? A Salesperson's Perspective. In: Kehoe, W.J. and Whitten, L.K., Eds., Advances in Marketing: Sensory Marketing the Next Frontier, Society for Marketing Advances, Mobile, 10-22.

[17] Meng, D. and Tian, G. (2011) Price and Advertising Signals of Product Quality with Minimum Demand. 45-47. 


\section{Appendix}

\section{Questionnaire}

This questionnaire designed to collect data for my thesis (Master's student, Kish International Campus of Tehran University) has been developed to investigate the role of price in determining the quality of products in Kish Island. You will be asked to answer the question by marking items. Certainly, your precision will help us to achieve real results.

\section{Section I}

1) Gender:

2) Age:

Less than $20 \bigcirc \quad 20-30 \bigcirc \quad 30-40 \bigcirc \quad$ over $40 \bigcirc$

3) Education:

Below diploma $\bigcirc$ Diploma $\bigcirc$ Associate $\bigcirc$ BA $\bigcirc$ Higher education $\bigcirc$

4) The level of income (Tomans):

Less than 1 million $\bigcirc \quad$ Between 1 and 2 million $\bigcirc \quad$ Between 2 and 3 million $\bigcirc \quad$ Over 3 million $\bigcirc$

5. Are you a resident of Kish Island?

Yes $\bigcirc \quad$ No $\bigcirc$

\section{Section II}

How important are the following signs when buying a color LED TV?

6) Brand (like Sony or Samsung)

Very highly $\bigcirc \quad$ Highly $\bigcirc \quad$ On average $\bigcirc \quad$ Lowly $\bigcirc \quad$ Very lowly $\bigcirc$

7) Price

Very highly $\bigcirc \quad$ Highly $\bigcirc \quad$ On average $\bigcirc \quad$ Lowly $\bigcirc \quad$ Very lowly $\bigcirc$

8) The product features (such as resolution, appearance, sound quality, etc.)

Very highly $\bigcirc$ Highly $\bigcirc$ On average $\bigcirc$ Lowly $\bigcirc$ Very lowly $\bigcirc$

9. Store

Very highly $\bigcirc \quad$ Highly $\bigcirc \quad$ On average $\bigcirc \quad$ Lowly $\bigcirc \quad$ Very lowly $\bigcirc$

10. Advertising

Very high $\bigcirc \quad$ High $\bigcirc \quad$ Medium $\bigcirc \quad$ Low $\bigcirc \quad$ Very low $\bigcirc$

11. Brand loyalty

Very high $\bigcirc$

12. Store loyalty

Very high $\bigcirc$

High $\bigcirc \quad$ Medium $\bigcirc \quad$ Low $\bigcirc \quad$ Very low $\bigcirc$

How much the following signs are indicative of the quality of color LED TV?

13) Brand (like Sony or Samsung)
Very highly
High $\mathrm{O}$
Medium $\bigcirc$
Low $\bigcirc$
Very low $\bigcirc$

14) Price

Very high $\bigcirc \quad$ High $\bigcirc \quad$ Medium $\bigcirc \quad$ Low $\bigcirc \quad$ Very low $\bigcirc$

15) The product features (such as resolution, appearance, sound quality, etc.) Very high $\bigcirc$ High $\bigcirc$ Medium $\bigcirc$ Low $\bigcirc$ Very low $\bigcirc$

16) Store Very high $\bigcirc \quad$ High $\bigcirc \quad$ Medium $\bigcirc \quad$ Low $\bigcirc \quad$ Very low $\bigcirc$

17) Advertising Very high $\bigcirc \quad$ High $\bigcirc \quad$ Medium $\bigcirc \quad$ Low $\bigcirc \quad$ Very low $\bigcirc$

18) Brand loyalty Very high $\bigcirc$

19) Store loyalty Very high $\bigcirc$

High $\bigcirc \quad$ Medium $\bigcirc \quad$ Low $\bigcirc \quad$ Very low $\bigcirc$

High $\bigcirc \quad$ Medium $\bigcirc \quad$ Low $\bigcirc \quad$ Very low $\bigcirc$

How do you evaluate the quality of color LED TVs by following prices?

20) Less than $500 \mathrm{~T}$

Excellent $\bigcirc$

Good $\bigcirc \quad$ Fair $\bigcirc$

Poor $\bigcirc \quad$ Very poor $\bigcirc$ 
21) Between 500,000 to $1,000,000 \mathrm{~T}$

Excellent $\bigcirc$ Good $\bigcirc$ Fair $\bigcirc \quad$ Poor $\bigcirc \quad$ Very poor $\bigcirc$

22) Between $1,000,000$ to 2,000,000 $\mathrm{T}$

Excellent $\bigcirc$ Good $\bigcirc$ Fair $\bigcirc \quad$ Poor $\bigcirc$ Very poor $\bigcirc$

23) Between 2,000,000 to 3,000,000 $\mathrm{T}$

Excellent $\bigcirc$ Good $\bigcirc$ Fair $\bigcirc \quad$ Poor $\bigcirc$ Very poor $\bigcirc$

24) Between $3,000,000$ to $5,000,000 \mathrm{~T}$

Excellent $\bigcirc$ Good $\bigcirc$ Fair $\bigcirc \quad$ Poor $\bigcirc$ Very poor $\bigcirc$

25) More than 5 million $T$
Excellent $\bigcirc$
Good $\bigcirc$
Fair $\bigcirc$
Poor $\bigcirc$
Very poor $\bigcirc$

How is the quality of products in each of these markets?

26) Arab market Excellent $\bigcirc$

27) Business center Excellent $\bigcirc$

28) Pardis market Excellent $\bigcirc$

Good $\bigcirc \quad$ Fair $\bigcirc$

Poor $\bigcirc$

Very poor $\bigcirc$

Good $\bigcirc \quad$ Fair $\bigcirc$

Poor $\bigcirc$

Very poor $\bigcirc$

Good $\bigcirc \quad$ Fair $\bigcirc$

Poor $\bigcirc$

Very poor $\bigcirc$

\section{Section III}

How important are the following signs when buying a T-shirt?

1) Brand (like Adidas or Nice)

Very high $\bigcirc \quad$ High $\bigcirc \quad$ Medium $\bigcirc \quad$ Low $\bigcirc \quad$ Very low $\bigcirc$

2) Price

Very high $\bigcirc \quad$ High $\bigcirc \quad$ Medium $\bigcirc \quad$ Low
3) The product features (such as appearance, color, fabric, etc.)

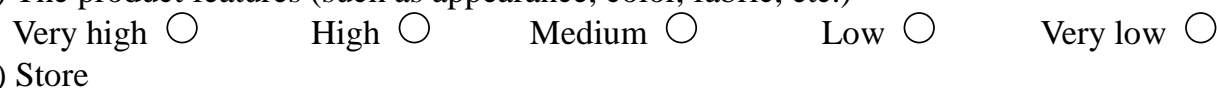

4) Store

Very high $\mathrm{O}$

5) Advertising

Very high $\bigcirc$

High $\bigcirc \quad$ Medium $\bigcirc$

Low $\bigcirc$

Very low $\bigcirc$

6) Brand loyalty

Very high $\bigcirc$

High $\bigcirc \quad$ Medium $\bigcirc$

Low $\bigcirc$

Very low $\bigcirc$

7) Store loyalty

Very high $\bigcirc$

High $\bigcirc \quad$ Medium $\bigcirc$

Low $\bigcirc$

Very low $\bigcirc$

High $\bigcirc \quad$ Medium $\bigcirc$

Low $\bigcirc$

Very low $\bigcirc$

How much the following signs are indicative of the quality of t-shirt?

8) Brand (like Adidas or Nice)

Very high $\bigcirc$ High $\bigcirc$

9) Price

Very high $\bigcirc$

High $\bigcirc \quad$ Medium $\bigcirc$

Low $\bigcirc$

Very low $\bigcirc$

0) The product features (such as appearance, color, fabric, etc.) Very high $\bigcirc$

High $\bigcirc$

Medium $\bigcirc$

Low

11) Store

Very high $\bigcirc$

High $\bigcirc$

Medium $\bigcirc$

Low $\bigcirc$

Very low $\bigcirc$

12) Advertising Very high $\bigcirc$

13) Brand loyalty Very high $\bigcirc$

High $\bigcirc \quad$ Medium $\bigcirc$

Low $\bigcirc$

Very low $\bigcirc$

4) Store loyalty

Very high $\bigcirc$

\section{High $\bigcirc \quad$ Medium $\bigcirc$}

Low $\bigcirc$

Very low $\bigcirc$

How do you evaluate the quality of $t$-shirts by following prices?

High $\bigcirc \quad$ Medium $\bigcirc$

Low $\bigcirc$

Very low $\bigcirc$

Very low $\bigcirc$

15) Less than $20,000 \mathrm{~T}$

Excellent $\bigcirc \quad$ Good $\bigcirc$

Fair $\bigcirc$

Poor $\bigcirc$

Very poor $\bigcirc$

16) Between 20,000 to 30,000 T 
Excellent $\bigcirc \quad$ Good $\bigcirc \quad$ Fair $\bigcirc \quad$ Poor $\bigcirc \quad$ Very poor $\bigcirc$

17) Between 30,000 to $50,000 \mathrm{~T}$ Excellent $\bigcirc \quad$ Good $\bigcirc$

18) Between 50,000 to $100,000 \mathrm{~T}$ Excellent $\bigcirc \quad$ Good $\bigcirc$

19) Between 100,000 to $200,000 \mathrm{~T}$ Excellent $\bigcirc$ Good $\bigcirc$ Fair $\bigcirc \quad$ Poor $\bigcirc$ Very poor $\bigcirc$

20) More than 200,000 $\mathrm{T}$
Excellent $\bigcirc$
Good $\bigcirc$

Fair $\bigcirc$

Poor $\bigcirc \quad$ Very poor $\bigcirc$

Fair $\bigcirc \quad$ Poor $\bigcirc \quad$ Very poor $\bigcirc$

Poor $\bigcirc$

Very poor $\bigcirc$

How is the quality of products in each of these markets?

21) Arab market Excellent $\bigcirc$

22) Business center

23) Pardis market

Good $\bigcirc \quad$ Fair $\bigcirc$

Poor $\bigcirc$

Very poor $\bigcirc$

Good $\bigcirc \quad$ Fair $\bigcirc$

Poor $\bigcirc$

Very poor $\bigcirc$ Excellent $\bigcirc$

Good $\bigcirc \quad$ Fair $\bigcirc$

Poor $\bigcirc$

Very poor $\bigcirc$

\section{Section IV}

How important are the following signs when buying a toothpaste?

1) Brand (like Signal or Daroogar)

Very high $\bigcirc \quad$ High $\bigcirc$ Medium $\bigcirc$ Low $\bigcirc$ Very low $\bigcirc$

2) Price

Very high $\bigcirc \quad$ High $\bigcirc \quad$ Medium $\bigcirc \quad$ Low $\bigcirc$ Very low $\bigcirc$

3) The product features (such as brightening power, appearance, size, etc.) Very high $\bigcirc$ High $\bigcirc$ Medium $\bigcirc$ Low $\bigcirc$ Very low $\bigcirc$

4) Store Very high $\bigcirc \quad$ High $\bigcirc \quad$ Medium $\bigcirc \quad$ Low $\bigcirc \quad$ Very low $\bigcirc$

5) Advertising

Very high $\bigcirc$

High $\bigcirc \quad$ Medium $\bigcirc \quad$ Low $\bigcirc \quad$ Very low $\bigcirc$

6) Brand loyalty

Very high $\bigcirc$

High $\bigcirc \quad$ Medium $\bigcirc \quad$ Low $\bigcirc \quad$ Very low $\bigcirc$

7) Store loyalty

Very high $\bigcirc$

High $\bigcirc \quad$ Medium $\bigcirc$

Low $\bigcirc$

Very low $\bigcirc$

How much the following signs are indicative of the quality of t-shirt?

8) Brand (like Signal or Daroogar)

$\begin{array}{llll}\text { Very high } \bigcirc & \text { High } \bigcirc & \text { Medium } \bigcirc & \text { Low } \bigcirc\end{array}$ Very low $\bigcirc$

Very high $\bigcirc \quad$ High $\bigcirc \quad$ Medium $\bigcirc \quad$ Low $\bigcirc \quad$ Very low $\bigcirc$

10) The product features (such as brightening power, appearance, size, etc.) Very high $\bigcirc$ High $\bigcirc$ Medium $\bigcirc$ Low $\bigcirc$ Very low $\bigcirc$

11) Store Very high $\bigcirc \quad$ High $\bigcirc \quad$ Medium $\bigcirc \quad$ Low $\bigcirc \quad$ Very low $\bigcirc$

12) Advertising Very high $\bigcirc$

13) Brand loyalty Very high $\mathrm{O}$

14) Store loyalty Very high $\bigcirc$

High $\bigcirc \quad$ Medium $\bigcirc$

Low $\bigcirc$

Very low $\bigcirc$

High $\bigcirc \quad$ Medium $\bigcirc \quad$ Low $\bigcirc \quad$ Very low $\bigcirc$

How do you evaluate the quality of t-shirts by following prices?

15) Less than 2,000 $\mathrm{T}$
Excellent $\bigcirc$
Good $\bigcirc$
Fair $\bigcirc$
Poor $\bigcirc$
Very poor $\bigcirc$

16) Between 2,000 to $3,000 \mathrm{~T}$

Excellent $\bigcirc \quad$ Good $\bigcirc$ Fair $\bigcirc$

Poor $\bigcirc \quad$ Very poor $\bigcirc$ 
17) Between 3,000 to $5,000 \mathrm{~T}$ Excellent $\bigcirc \quad$ Good $\bigcirc$

Fair $\bigcirc$

Poor $\bigcirc$

Very poor $\bigcirc$

18) Between 5,000 to $7,000 \mathrm{~T}$ Excellent $\bigcirc \quad$ Good $O$

Fair $\bigcirc$

Poor $\bigcirc$

Very poor $\bigcirc$

19) Between 7,000 to $10,000 \mathrm{~T}$ Excellent $\bigcirc \quad$ Good $\bigcirc$

Fair $\bigcirc$

Poor $\bigcirc$

Very poor $\bigcirc$

20) More than 10,000 $\mathrm{T}$
Excellent $\bigcirc$
Good $\bigcirc$

Fair $\bigcirc$

Poor $\bigcirc$

Very poor $\bigcirc$

How is the quality of products in each of these markets?

21) Arab market Excellent $\bigcirc$

Good $\bigcirc$

Fair $\bigcirc$

Poor $\bigcirc$

Very poor $\bigcirc$

22) Business center Excellent $\bigcirc$

Good $\bigcirc \quad$ Fair $\bigcirc$

Poor $\bigcirc$

Very poor $\bigcirc$

23) Pardis market

Excellent $\bigcirc$

Good $\bigcirc$

Fair $\bigcirc$

Poor $\bigcirc$

Very poor $\bigcirc$ 